It was found necessary to insert a clause in the Act allowing a judge to order any needful experiments by a medical jurist. But this may cause, and has already caused, injurious delays, and it would be desirable for each person engaged in this defartment of scientific work to take out the nece-sary license beforehand.

$\S 7$. The above is only a brief enumeration of some of the more striking and illustrative cases in which the objects proposed by experiments on animals have been attained. In some of these success has been brilliant and complete, in others comparative and needing fuller development. In some the results have been the direct and exclusive consequence of the experiments, in others they have been due to these either as confirming or correcting previous conjectures, or as guiding clinical research, or as suggesting fruitful investigations by other methods.

Without exaggerating its extent and cogency, the evidence is ample to show, what no one conversant with the subject doubts, that the great strides made in the practice of medicine during the last fifty years have been chiefly due to the exact scientific experimental inquiries of this epoch. In fact, experience fully bears out what reason demonstrates and authority confirms, that medicine rests chiefly upon physiology, and that physiology cannot advance without experiments.

The prejudices excited by the account of long past or distant abuses of the right and duty of experiment will, it may be hoped, be dispelled (as in many cases they have been) by increased knowledge of the facts; while those which have been raised by reckless misstatement will subside on candid investigation. If any fear remain that evils which do not now exist may possibly arise in future, it may be dispelled by a consideration of the stringent regulations of the existing law, even if carried out with the utmost desire not to obstruct demonstrably useful scientific work.

But it is on the scientific investigator himself that the responsibility must ultimately rest of determining what is the best method of accomplishing a given scientific result, and by what means the greatest possible result may be obtained at the least possible cost of suffering. If restrictions are supposed to be neces sary to control the conduct of careless individuals, let them be continued; but so long as scientific men exercise their responsibility in the humane spirit which has hitherto guided investigation in this country, they have a right to ask that no unnecessary obstacles should be placed in their way.

It is therefore hoped that such a decided and influentia expression of opinion will be made in Parliament as will not only rebuke ill-advised attempts to totally abolish one of the most important methods of natural knowledge, and an indispensable method for the improvement of medicine; but will also strengthen the hands of the Government in administering the law, so as not to interfere with the just claims of science and with the paramount claims of human suffering.

\section{THE BRITISH ASSOCIATION AND CANADA}

T HE following circular is being sent out by the British Association for the Advancement of Science :-

\section{" 22, Albemarle Street, London, W., March 19}

"SIR,-We have been instructed by the Council of the British Association to communicate to you the accompanying letter from Sir A. T. Galt, G.C.M.G., High Commissioner for Canada. This letter was written in reply to one addressed by us to him, making certain inquiries with reference to the invitation to visit Montreal in $\mathbf{1 8 8 4}$, which was accepted by the General Committee at the Southampton meeting last year. In that letter it was our endeavour to obtain information as accurate as possible concerning the probable expense of the journey to and from Montreal, including a stay of a fortnight or three weeks in Canada (in addition to the period of the meeting), and excursions to some of the more interesting localities. From the statements in Sir A. T. Galt's letter, the members will be able to form an opinion as to the probable cost of the expedition, the amount of which must obviously, to a considerable extent, depend upon the length of time which they are willing to devote to the visit.

"It is obviously most important to secure that the Montreal meeting should be attended by a strong and thoroughly representative body of members, so that the gathering may be both creditable to the Association and gratifying to our Canadian hosts. Further, many arrangements must be made prior to the meeting, and these must be settled considerably in advance of the u-ual dates. It will therefore greatly aid the Council and those who will have to carry out their instructions in detail, if you will be so good as to state your intention concerning the visit to Montreal by filling up the annexed form and returning it as addressed before April r4.

"We remain, sir, your obedient servants, "C. W. SIEMENS, President

“A. W. Williamson, General Treasurer "Douglas Galton, \} General "A. G. VERnoN HarcourT, $\}$ Secretaries "T. G. BONNEY, Secretary"

“" 9, Victoria Chambers, London, S. W., March 3, r883

" Dear Sir,---I have to refer you to your letter of November 28 on the subject of the visit of the British Association for the Advancement of Science to Montreal in 1884 , in accordance with the decision of the general committee, at their meeting at Southampton on Augu-t 28 last, and to inform you that I have received a communication from the Chairman of the Montreal Invitation Committee (T. Sterry Hunt, M.A., L.L.D., F.R.S.), containing some detailed information on the different matters you mentioned to me.

"It is my pleasant duty to state that the inhabitants of the city of Montreal received with satisfaction the intimation that the Association had d cided to honour them with a visit, and much public spirit has already been manifested in the desire that everything should be done to make the occasion worthy of the illustrious body and of the country. Committees on invitation, on finance, and on conveyance have already been formed, and a guarantee fund opened very satisfactorily; while the Government of the Dominion, in view of the widespread interest which the matter has awakened, will ask Parliament during its present session to vote a considerable sum $(\$ 20,000)$ as a contribution to the funds that will be subscribed by the public. Montreal, I may add, is not without experience of the requirements of an important meeting of the kind, having twice been favoured with vi its from the American Association, the last occasion bei'g in I882, when an attendance of more than 900 members anc associates was registered, and the Association, with its nine sections, found ample accommodation in the buildings of McGill Uni. versity.

"I propose to answer your questions in the same order as that in which they were placed in your communication, but it will not be possible for me'to do so in such full detail as I should like so far in advance of the time of their application, especially in regard to the cost of conveyance and the various expeditions to be arranged. I trust, however, the fullowing information will be sufficient for the purpose of giving to the members of your distinguished Association an idea of the probahle expenses they may be called upon to defray during their stay in Canada.

"(I.) "The cost of the journey to and from Montreal to one who makes it as a member of the Association or as the near relative of a member.'

"Dr. Sterry Hunt desires me to say that the committee will arrange fifty free passages for the conveyance of the officers of the Association whose attendance is indispensable at its annual meetings. The funds at the disposal of the committee will also enable it to negotiate with the steamship companies for the reduction of the ordinary ocean passages in favour of bon $\hat{a}$ fidc members of the As ociation. Two courses are open in which this can be done.

"( 1 ) To arrange for a number of passages to be offered at the single rate for the double journey-say $15 l$. Ios.

“(2) For a general reduction, so far as the funds will permit. "Either of these plans can be adopted, but the steamship companies, although fully disposed to entertain the matter, do not care to make any definite engagements so far in advance, which will, I am sure, be readily understood. I am to state, however, that the committee is prepared, with the aid of the Government grant, to devote $3000 l$. to these purposes alone.

"(II.) 'The cost of board and lodging per head per diem for the above during the week of the meeting at Montreal.'

"I cannot do better than quote a paragraph from Dr. Sterry Hunt's letter, in regard to 'this inquiry :-'In reply to Prof. Bonney's question as to the expenses of board and lodgin s for members of the British Association during the meeting in Montreal, the committee will give assurance that free entertainment will be provided for at least 150 , and probably for all other members who may attend.' 
"I may amplify this by stating for your information that the tariff of the Montreal botels ranges from $\$ 2$ 5cc. to $\$ 4$ per day inclusive, and that private accommodation can be obtained at much lower prices than in England.

"(III.) 'A scheme of expeditions which would occupy from two to three weeks sub equent to the meeting, and the cost of each of them.'

"Dr. Sterry Hunt says :- 'As to the proposed excursions, we are prepared to say that the Grand Trunk, the Canada Pacific, and the Intercolonial Railways will furnish free transportation over their lines throughout the dominion of Canada from Nova Scotia to the $\mathrm{N}$ orth-West. The Canada Pacific will also arrange an excursion to the Rocky Mountains, and the Grand Trunk one to the Great Lakes (note : this will include Niagara) and Chicago; while the South-Eastern Railway will do the same for the White Mountains and Portland and Boston. For an excursion of thi- kind, occupying three or four weeks, tourists should be provided with, :ay, $20 l$. in money for hotels, carriages, and other incidental expenses, though it is possible that a less sum than this would be needed.'

"I am inclosing a copy of a circular that has been prepared by the Montreal committee. It contains interesting information, and it will be seen that the arrangements are in the hands of representative and eminent men.

"I believe from the information that reaches me that the Assnciation will receive the addition of a considerable number of associates in Canada, and that the visit will give an impetus to scientific research in the Dominion such as it has not experienced before. It is confidently anticipated also that the American Association will hold its meeting in 1884 at a convenient time and place, affording an opportunity for scientific intercourse that I imagine does not often occur.

"I will gladly :upply any further information you may require if it is in my power to do so, and shall readily cooperate in any mea:ures having for their object the success of the metting of the British Association for the Advancement of Science at Montreal in 1884 .

"I am, dear Sir, your obedient servant, "A. T. Galt,

"High Commis sioner for Canada, and Vice-Chairman of the Montreal Citizens' Committee

"Prof. T. G. Bonney, M.A., F.R.S., F.G.S., \&c., "22, Albemarle Street, W."

\section{UNIVERSITY AND EDUCATIONAL \\ INTELLIGENCF}

OXFORD.-The Savilian Professorship of Geometry in the Uni. versity is vacant, and an election to the office will be held before the end of Trinity Term (July 7, I883). A Fellowsbip in New College is now annexed to the Professorship. The duty of the Profe-sor is to lecture and give instruction in pure and analytical geometry. The combined emoluments of the office from both sources will be, fur the present, $700 l$. a year, but may possibly hereafter be increased to an amount not exceeding $900 l$. a year. The qualifications required in candidates for the Savilian Professor.hips by the existing Statutes of the University are as follows :- "Hos Professores sive lectores, prout voluit findator, statuimus et decernimu: fore per etuis temporibus eligendos ex honinibus bonæ famæe et conversationis honestæ, ex quacunque natione orbis Christiani, et cujuscunque ordinis sive profes-ionis, qui in mathematicis instructissimi sint, et annos ad minimum sex et viginti nati ; et, si Angli fuerint, sint ad minimum Artium Magistri." Candidates are requested to send to the Registrar of the University their applications, and any documents which they may wi-h to submit to the Electors, on or before Thursday, May $3 \mathbf{I}$.

VICTORIA UNIVERSITY. -At a meeting of the University Court on March 30, Vice-Chancellor Greenwood laid on the table the supplementary charter, dated March 20, 1883, enabling the University to confer degrees and distinctions in medicine and surgery. After some discussion it was resolved that the Council be empowered and instructed to appoint external examiners in medicine and surgery for a limited period, and to appoint certain lecturers of the University to act as University examiners ; also to prepare, after a report from the General Board of Studies, a statute or statutes and regulations relating to degrees in medicine and surgery for the consideration of the Court, and also to report of the subsequent appointment of external examiners in medicine and surgery, in accordance with the recommendation of the University Council. The Council were instructed to ascertain whether the University charier would allow of the same facilities that had been given to Owens College students being extended to the students of other colleges when those colleges sought admission to the University. The Council were of opinion that such facilities should certainly be given.

\section{SOCIETIES AND ACADEMIES LONDON}

Linntan Society, March 15.--Frank Crisp, treasurer and vice-president, in the chair.-Dr. T. S. Cobbold read a paper on Simondsia paradoxa, and on its probable affinity with Spherularia bombi. Thirty years ago Prof. Simonds discovered a remarkable parasite within cysts in the stomach of a wild boar which died in the Zoological Gardens, London. Prof. Simonds regarded the worm as a species of Strongylus, but Dr. Colibold in I864 suggested its affinities might probably be nearer the genus Spiroptera, then naming it Simondsia. The original drawings unfortunately were lost, and only quite lately, along with the specimens, they have turned up and have enabled Dr. Cobbold to investigate them more closely. He arrives at the conclu-ion that Simondsia is a genus of endoparasitic nematodes in which the female is encysted and furıished with an external and much enlarged uterus, whose walls expand into branches terminating in crea. The male is $\frac{1}{2}$ inch and the female $\frac{6}{10}$ inch long. Moreover, it is now found that what was at first regarded as the head turns out to be the tail, so that supposed Strongyloid character is incorrect. Taking into account $\mathrm{u}$ hat is known of Spharularia bombi as interpreted by Schneider, and whose views are universally accepted, it appears that Simondsia, though unique, yet approaches towards Spharularia in respect of the enormously developed female reproductive organ, which in both lies out side the body proper. Until Sir J. Lubbock's memoir on Sphcerularia appeared, the so-called male had never been indi. cated; but, judged by Schneider's interpretation of that genus, the male is still unknown. Dr. Cobbold points out that the socalled rosette in Simondsia is morpholngically a prolapsed uterus furnisted with two egg-containing branches; he regards the external branched processes as homologous with the sphærules of Spharularia, whilst the ultimate cæcal capsules have nothing comparable to them in nature.-A paper was read on the moths of the family Urapteridæ in the British Museum, by Artlur G. Butler. The author, basing distinctions on wing neuration and other characters, redistributes the family, and indicates the following new genera :-Tristrophis, Gonorthus, Sirinpteris, Nepheloleuca, Thinopteryx, Xeropteryx, and Eischropteryx.The eighteenth contribution to the mollusca of the Challenger Expecition, by the Rev. R. Boog-Watson was read, in which the author treats of the family Tornatellidæ, therein describing six new species of the genus Actaon.

Geological Society, March 7.- J. W. Hulke, F.R.S., president, in the chair.-Messrs. Thomas Gustav Hawley, Richard Lydeklier, and J. O'Donoghue were elected Fellows, and M. F. L. Cornet, of Mons, a Foreign Correspondent of the Society. - The following communications were read :-On Gray and Milne's sei mographic apparatus, by Thomas Gray, B.Sc., F.R.S.E. Communicated by the President. This apparatus was stated to have for its object the registration of the time of occurrence, the duration, and the nature, magnitude, and period of the motions of the earth during an earthquake. The instrument was made by Mr. James White, Glasgow, and is to be used by Prof. John Milne in his investigations in Japan. In this apfaratus two mutually rectangular components of the horizontal motion of the earth are recorded on a sheet of smoked paper wound round a drum, kept continuously in motion by clockwork, by means of two conical pendulum-seismographs. The vertical motion is recorded on the same sheet of paper by means of a compensated-spring seismograph. In details these instraments differ considerably from those described in the Philosophical Magazine for September, I88I, but the principle is the same. The time of cccurrence of an earthquake is determined by causing the circuit of two electromagnets to be closed by the shaking. One of these magnets relieves a mechanism, forming part of a time-keeper, which caus es the dial of the timepiece to come suddenly forward on the hands and then move back to its original position. The hands are provided 